\title{
SS モニタリングネットワークに基づく 東京湾への浮遊土砂供給特性の把握 SUSPENDED-SEDIMENT TRANSPORTS FLOWING INTO TOKYO BAY WITH A SS MONITORING NETWORK
}

\author{
田中健太郎 ${ }^{1}$ - 二瓶泰雄 ${ }^{2}$ \\ Kentaro TANAKA and Yasuo NIHEI \\ 1 学生員 学 (工) 東京理科大学大学院 理工学研究科土木工学専攻修士課程 \\ （干278-8510 千葉県野田市山崎2641） \\ 2正会員 博 (工) 東京理科大学准教授 理工学部土木工学科（同上）
}

\begin{abstract}
For comprehensive management of sediments of inner bays, it is important to understand the suspended-sediment transports from the watershed through rivers flowing into inner bays. However the sediment transport have not been understood especially under flood-flow conditions due to few continuous monitoring data for suspended sediment transports. For this purpose, we have installed turbidity sensors in the influent rivers into Tokyo Bay to continuously monitor SS trasnports. The observed results indicate that the coefficient $b$ in sediment rating curve $\left(L=a Q^{b}\right)$ are closely related to land use of the watershed. Total SS transports flowing into Tokyo Bay were annually $0.6-2.5 * 10^{6}$ ton. The SS trasnports in Edogawa, Arakawa and Tamagawa Rivers are $66 \%$ of total SS transports.
\end{abstract}

Key Words : suspended-solid transport, sediment rating curve, Tokyo Bay, turbidity, monitoring network

\section{1. 序論}

内湾に対する水質総量規制では, CODの規制に始まり， 第五次において全窒素 T-Nや全リン T-Pが対象項目とし て取り込まれている1)。この取り組みを始めとした様々 な陸域対策にも関わらず，東京湾や伊勢湾などの重要内 湾では水質環境は横ばい傾向であり, 貧酸素水塊の拡大 傾向すら報告されている ${ }^{2)}$. そのため, 今後の総量規制 における新たな水質目標として透明度や底層 DO を取り 込む検討も開始されている ${ }^{3)}$.

このような水質総量規制を推進し，かつ，陸域対策の 効果を適切に評価するには, 精度上や適用範囲に限界が ある原単位法 ${ }^{4)}$ とは別に，高精度な陸域環境負荷モ二タ リングを行う必要がある. 一般に，平常時の水質データ は月一回の頻度で継続的に計測されており，そのデータ ベースも充実している. その一方，高負荷となる出水時 の水質データは非常に限定されており ${ }^{5)}$, これが陸域環 境負荷評価の精度向上のボトルネックとなっている. そ のため, 内湾環境評価を念頭においた陸域環境負荷モ二 タリングネットワークの構築が不可欠である.

その際に必要となるモニタリング項目としては，水質 総量規制に取り上げられているCODやN, Pのみならず, 浮遊物質 (SS) も必要となる. 河川を経由して内湾に流 入する SS 輸送量は, 前述した新たな水質目標となる透明
度の構成要素になることに加えて，沿岸部の浅場・干潟 の形成プロセスに大きな影響を与える.さらに, SS は栄 養塩や有機物，重金属のキャリア（運搬物質）の役割を 担っており，陸域から内湾に供給される浮遊土砂供給量 を把握することは極めて重要である.

内湾流域における土砂輸送量モニタリングに関しては, 台風出水時において大量の土砂が輸送されることを考慮 すると，光学式センサ一等による連続観測を行う必要が ある.しかしながら，このような連続モニタリングを流 域全体にわたり実施した例は，筑後川流域における横山 らの研究の が挙げられる程度であり, 内湾環境評価に耐 え得る観測体制は取られていない. 本研究で対象とする 東京湾流域では，多摩川や江戸川の単発的な調査 ${ }^{7) ~ 9) ~}$ やダム堆砂データを用いた流域全体の土砂生産量の推定 9) が行われている程度であり, 結果として, 東京湾に流 入する浮遊土砂輸送量の実態すら不明である.

このような背景に基づいて，著者らは，東京湾を対象 として, 内湾環境評価に必要な SS モニタリングネットワ 一クを構築している 10)，11) 。具体的には，東京湾へ流入 する主要 10 河川のうち 7 河川において, 光学式濁度計等 を用いた浮遊土砂輸送量の長期連続計測を早くて2006年 度から実施し現在でも継続している。本研究では，さら に蓄積した多くの観測データを解析し, 様々な流域土地 利用条件と $L-Q$ 関係 $(L:$ 浮遊土砂輸送量, $Q$ : 流量 $)$ の 


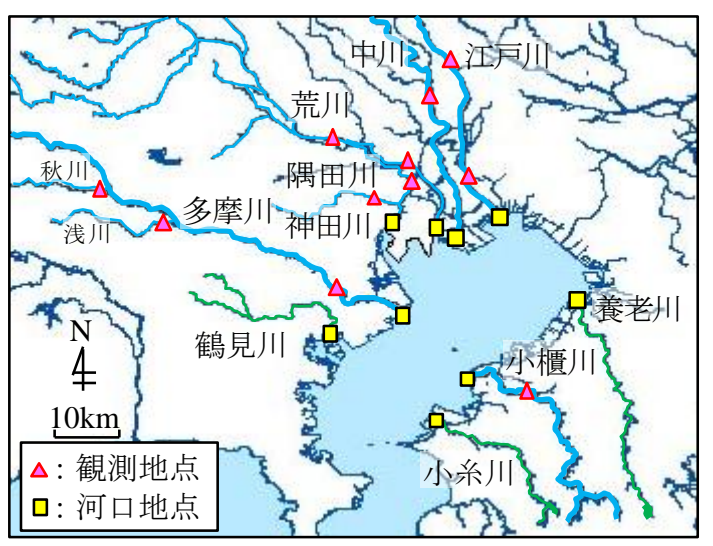

図-1 観測地点

特徴を検討し，それらの結果に基づいて東京湾への浮遊 土砂供給量の経年変化を推定することを試みる.

\section{2. 現地観測の概要}

\section{（1）東京湾流域の概要}

本研究の観測フィールドは, 神奈川県観音崎と千葉県 富津岬を結ぶ線より以北とする東京湾の流域であり，そ の流域面積は 7000km²（江戸川については江戸川のみの 流域面積を使用している）に及ぶ．東京湾に流入する河 川は大小 36 あるが, 公共用水域水質測定が行われている 河川は26である.このうち主要流入河川としては, 表-1 に示寸ように, 江戸川, 多摩川, 荒川, 隅田川, 神田川, 中川, 小櫃川, 養老川, 小糸川, 鶴見川の計 10 河川存在 しており，これらの流域面積の総和は $6257 \mathrm{~km}^{2}$ であり全 体の $89.3 \%$ を占めている. なお，神田川は隅田川の支川 であり直接東京湾に流入しないが，隅田川本川とは水質 特性が異なるため, ここでは別個に取り扱う。 また, 江 戸川は利根川から分派し，その分派率が約 $25 \%$ であるの で ${ }^{12)}$ ，江戸川分派地点の流域データに 0.25 倍したものに 江戸川のデータを加えた結果も表示している.

\section{（2）SS モニタリングネットワークについて}

本 SS モニタリングネットワークとしては，主要 10 河 川のうち江戸川, 多摩川, 荒川, 隅田川, 神田川, 中川, 小樌川の計 7河川において浮遊土砂輸送量の常時・自動 連続観測を長期間行っている. 各河川における観測地点 は，図一1 中の $\triangle \mathrm{N}^{2} の$ 位置に設けられており，江戸川で は野田橋（河口より $+39 \mathrm{~km} ）$ と市川橋 $(+13 \mathrm{~km})$ ，荒川で は笹目橋 $(+29 \mathrm{~km})$ と西新井橋 $(+13 \mathrm{~km})$ ，隅田川・白髧 橋 $(+9 \mathrm{~km})$ ，神田川では一休橋 (隅田川合流点より+6km) 之和田見橋 $(+12 \mathrm{~km})$, 中川・八条橋 $(+27 \mathrm{~km})$, 小櫃川・ 富川橋 $(+14 \mathrm{~km})$ であり, 多摩川水系では本川・調布堰 $(+13 \mathrm{~km})$ に加えて，支川の秋川・東秋留橋（多摩川合 流点から+3km)，浅川・高幡橋（多摩川合流点から+2km） である.このうち, 全域感潮河川である隅田川と感潮域
表一1 主要 10 河川における流域情報

$\left(* 1\right.$ 江戸川のみのデータ， $* 2$ 利根川（流域面積 $8764 \mathrm{~km}^{2} ）$ に分派率 (=0. 25) を掛けたものに*1 を加算したものである)

\begin{tabular}{c|c|ccccc}
\hline \multirow{2}{*}{ 河川 } & 流域面積 & \multicolumn{5}{|c}{ 土地利用 $[\%]$} \\
\cline { 3 - 7 } & {$\left[\mathrm{km}^{2}\right]$} & 山林 & 市街地 & 田 & 畑 & その他 \\
\hline \hline 江戸川 & $200^{* 1}$ & 10.8 & 58.1 & 4.7 & 18.8 & 7.6 \\
\cline { 2 - 7 } & $2391^{* 2}$ & 57.7 & 19.5 & 7.7 & 9.8 & 5.2 \\
\hline 多摩川 & 1240 & 50.9 & 35.2 & 0.7 & 5.9 & 7.2 \\
\hline 荒川 & 2300 & 52.9 & 24.5 & 5.5 & 7.4 & 9.8 \\
\hline 隅田川 & 535 & 1.0 & 46.0 & 35.0 & 11.0 & 7.0 \\
\hline 神田川 & 105 & 0.9 & 97.5 & 0.5 & 0.6 & 0.5 \\
\hline 中川 & 987 & 1.0 & 47.0 & 36.0 & 11.0 & 5.0 \\
\hline 小櫃川 & 267 & 62.6 & 7.6 & 7.3 & 4.1 & 18.4 \\
\hline 養老川 & 246 & 72.3 & 8.9 & 5.2 & 2.2 & 11.4 \\
\hline 小系川 & 142 & 47.7 & 19.3 & 5.5 & 2.6 & 25.0 \\
\hline 鶴見川 & 235 & 14.0 & 71.0 & 2.0 & 10.0 & 3.0 \\
\hline
\end{tabular}

表一2 各観測地点における機器設置状況と観測期間 $(\Delta$ はバケツ採水実施， $\times は$ は採水無しを意味する $)$

\begin{tabular}{|c|c|c|c|c|}
\hline 河川 & 観測地点 & 濁度計 & $\begin{array}{c}\text { 自動 } \\
\text { 採水機 }\end{array}$ & $\begin{array}{c}\text { 採水 } \\
\text { イベント数 }\end{array}$ \\
\hline \multirow{2}{*}{ 江戸川 } & 野田橋 & 2006-現在 & 2006-現在 & 11 \\
\hline & 市川橋 & 2010-現在 & $x$ & - \\
\hline 多摩川 & 調布堰 & 2006-現在 & 2006-現在 & 10 \\
\hline 浅川 & 高幡橋 & 2010-現在 & $x$ & - \\
\hline 秋川 & 東秋留橋 & 2010-現在 & $x$ & - \\
\hline \multirow{2}{*}{ 荒川 } & 䈎目橋 & 2006-2008 & 2006-2008 & 4 \\
\hline & 西新井橋 & 2008-現在 & 2009-現在 & 1 \\
\hline 隅田川 & 白髭橋 & 2007-現在 & 2008-2009 & 4 \\
\hline \multirow{2}{*}{ 神田川 } & 一休橋 & 2009-現在 & $\triangle$ & 1 \\
\hline & 和田見橋 & $x$ & 2010-現在 & 3 \\
\hline 中川 & 八条橋 & 2007-現在 & 2007-2009 & 3 \\
\hline 小櫃川 & 富川橋 & 2008-現在 & 2008-2009 & 4 \\
\hline
\end{tabular}

が長い荒川では観測地点は感潮区間に位置している。ま た，神田川・一休橋と中川・八条橋は塩分遡上はないが 潮汐による水位変化が伝播する範囲に位置している。 そ の他は順流域に存在する.

各地点の機器設置状況と観測期間を表一2 に示す。こ こでは，浮遊士砂輸送量の連続観測を行うために，光学 式濁度計（Compact-CLW，JFEアドバンテック侏製）によ る濁度観測 (時間間隔: 10２0 分間隔) と自動採水機 (6712 型ウォーターサンプラー，Teledyne ISCO製）による出水 時採水観測を実施している. 現在は7河川10地点におい て光学式濁度計による濁度観測を実施している.

採水サンプルの分析項目とその方法としては，濁度に は多項目水質計（WQC-24，東亜ディーケーケー侏製）を 用い, SS はガラス繊維ろ紙法により分析し，粒径分析に はレーザー回折式粒度分布測定装置（SALD-3100，（株） 島津製作所製）を用いる. なお，このモニタリングでは， 他の水質項目（強熱減量 IL や COD，T-N，T-P など）も 
計測しているため ${ }^{5}$, 本ネットワークでは SS のみなら ず陸域環境負荷に関連する項目もカバーしている.

\section{（3）データ解析の概要}

上記の観測結果に基づいて，(1)観測地点における浮遊 土砂輸送量と流量の関係性の把握に加えて，(2)各河川の 河口地点から東京湾への浮遊土砂供給量の推定, という 二種類の解析を行う。まず, (1) に際して, 浮遊土砂輸送 量算出に必要となる流量とSS の算定手順を述べる.まず, SSについては濁度から算定するが，それには河川毎に作 成された濁度と SS の相関式を用いる. 一方, 流量データ については，隅田川を除いて，二瓶ら ${ }^{12)}$ と同じである. すなわち, 江戸川や中川, 神田川, 小樌川は地点毎の $H-Q$ 式により, 多摩川では堰測法により流量值を与える. ま た，荒川では順流域末端（秋ヶ瀬堰，34km）の流量に流 入支川や下水処理場からの放流量を加算する. 隅田川で は, H-ADCP 計測と数值解析による河川流量モニタリン グシステム ${ }^{13)}$ による直接流量計測結果を用いる。なお, 本モニタリングは現在でも実施しているが，本論文にお けるデータ解析対象期間は 2009年までとする. また, 荒 川については 2008 年 10 月まで行われた笹目橋のみのデ ータをここでは採用する.

次に, (2)においては, 後述する方法により, 河川毎に 浮遊土砂輸送量 $L$ と流量 $Q$ の相関式（ $L-Q$ 式）を作成す る. 河口地点における流量については, 前述の二瓶ら ${ }^{12)}$ に準じて算出し, 得られた $L-Q$ 式を用いて河口地点から 東京湾への浮遊土砂供給量の時系列変化を算出寸る.こ こでは主要 10 河川を解析対象とし, 各河川における河口 地点は, 図-1中の黄色印で示寸位置である.

\section{3. 浮遊土砂輸送量と流量の関係}

\section{（1）生データと移動平均值の特徵}

本モニタリングネットワークにより得られた観測結果 の一例として, 江戸川・野田橋と多摩川・調布堰におけ る浮遊土砂輸送量 $L$ と流量 $Q$ の相関図を図一2に示寸. 図 中には, 各河川の全観測期間における観測生データ（青 印）とある流量範囲における移動平均值 (赤印) が表示 されている. それとともに, 一般的に $L-Q$ 式で用いられる べき関数の近似直線 ${ }^{14)}\left(L=a Q^{b}, a, b\right.$ : 係数 $)$ も合わ せて図示している. これより, 両河川共に, 同一流量で も浮遊土砂輸送量のバラツキが大きく, その様子は低流 量時ほど顕著となっている. これは, $L-Q$ 間の様々なヒス テリシス現象 ${ }^{15)}$ やファーストフラッシュ現象间による影 響が現れているものと考えられる. また, 生データは, 当然のことながら低水時の流量範囲に多く存在しており, 出現頻度が少ない大規模出水の流量範囲ほどデータ数が 少ない. そのため, 生データに対してそのまま $L Q$ 式の近

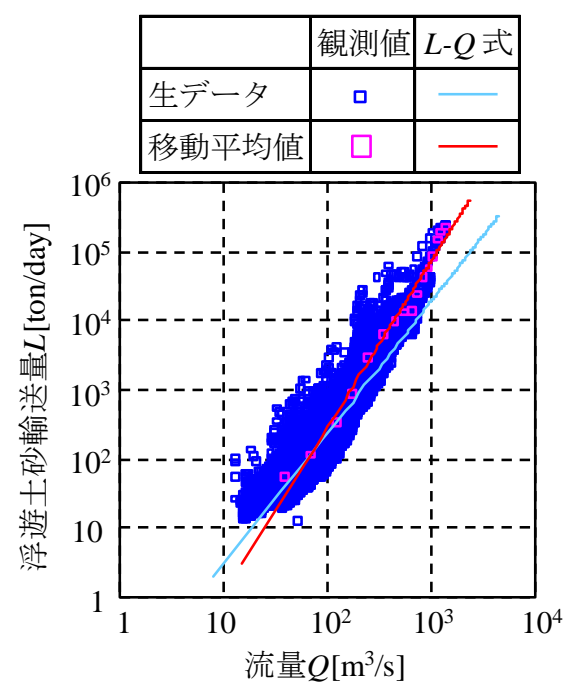

(a) 江戸川・野田橋

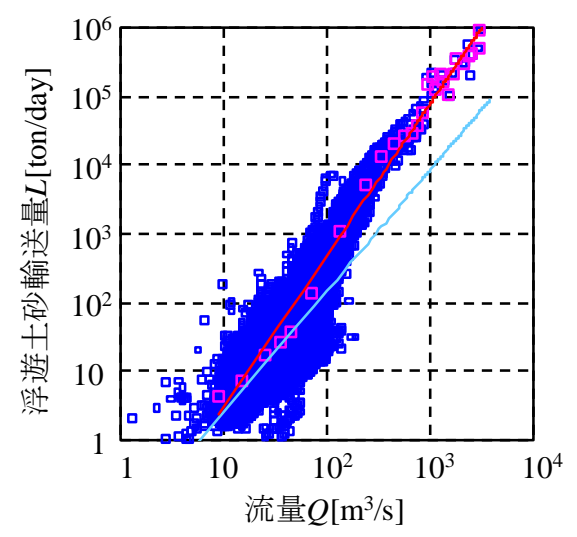

(b) 多摩川・調布堰

図-2 浮遊土砂輸送量 $L$ と流量 $Q$ 相関関係 （生データと移動平均值を表示）

似式を求めると, 図中の青線のように観測值とのずれが 大きく, 特に出水時の流量範囲で大きな差が生じている ことが分かる. そのため, このままでは高流量時の浮遊 土砂輸送量を過小評価する可能性があり, 精度向上のた めには流量範囲毎に $L-Q$ 式を分けるなどの工夫を要する ${ }^{17}$.

それに対して, $L-Q$ 関係の移動平均值を見てみると, 低 水時から出水時までバランスよくデータが存在するため, 得られる $L-Q$ 式は移動平均值に対して良好に近似されて いることが分かる，なお，本論文では，全流量範囲に一 つのL-Q式を作成しているが，図一2を詳細に見ると，流 量により $L-Q$ 式の傾きが異なっている. そのため, 流量依 存性を考慮した $L-Q$ 式 $^{18)}$ の作成が必要となるが，今後の 検討課題とする.

\section{（2） $L-Q$ 式の推定精度}

このように異なる方法で算出した $L Q$ 式の推定精度を検 証するために, 浮遊士砂輸送量の観測值と $L-Q$ 式による推 定值の相関図を図一3に示寸.ここでは, 前述したように, 生データ及び移動平均值に対する $L-Q$ 式を採用しており, 


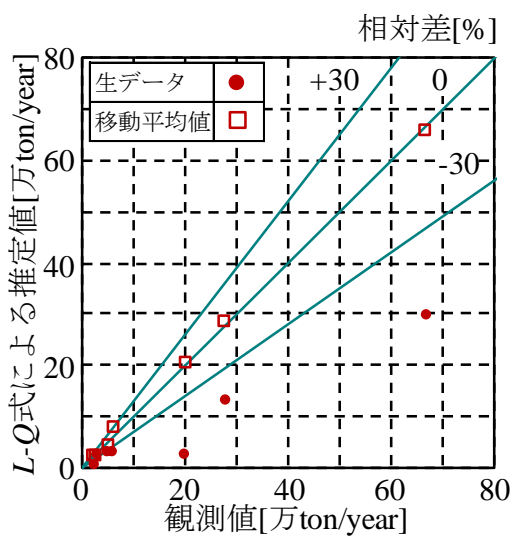

図-3 浮遊土砂輸送量に関する観測值と $L-Q$ 式による推定値 の比較（推定值には生データ及び移動平均値に対す る $L$ Q式を採用)

表-3 L-Q式中の係数 $a, b$ (下 3 つの河川は推定値, 他の 7 河川は観測値)

\begin{tabular}{c|c|c|c|c}
\hline \multirow{2}{*}{ 河川名 } & \multicolumn{2}{|c|}{ 生データ } & \multicolumn{2}{c}{ 移動平均 } \\
\cline { 2 - 5 } & $a$ & $b$ & $a$ & $b$ \\
\hline 江戸川 & 0.036 & 1.90 & 0.005 & 2.40 \\
\hline 荒川 & 0.084 & 1.78 & 0.055 & 1.95 \\
\hline 多摩川 & 0.047 & 1.75 & 0.019 & 2.21 \\
\hline 隅田川 & 0.918 & 1.09 & 0.132 & 1.72 \\
\hline 中川 & 0.191 & 1.53 & 0.082 & 1.80 \\
\hline 小樻川 & 0.111 & 2.34 & 0.507 & 1.92 \\
\hline 神田川 & 0.633 & 1.02 & 0.047 & 1.97 \\
\hline 鶴見川 & $\times$ & $\times$ & 0.425 & 1.99 \\
\hline 養老川 & $\times$ & $\times$ & 0.255 & 2.20 \\
\hline 小糸川 & $\times$ & $\times$ & 0.441 & 2.03 \\
\hline
\end{tabular}

そこで用いられた $L-Q$ 式中の係数 $a ， b$ は表一3に示す通り である．また，観測值とは連続計測された濁度データを SSに変換して得られた結果であり, それと推定值の差を 見やすくするために, 相対差 $0 \%$ と $30 \%$ を実線で表示し ている. なお，各河川における観測期間は異なるので, ここでは，観測地点毎の全観測期間に関する浮遊土砂輸 送量を年間值に換算した結果を採用している. これを見 ると, 生データに対する $L-Q$ 式の推定結果は, 観測值より もかなり小さくなっており,多くの河川では相対差が30\% 以上となっている. これは，図一2に示したように， $L-Q$ 式の傾きが小さいためであり, このことは表一3中の生デ 一タに対する係数 $b$ 小さいことからも確認できる.

それに対して, 移動平均值に対する $L Q$ 式の推定結果は, 生データに対する結果よりも観測值に近くなっており, 移動平均值データを用いることにより $L Q$ 式による浮遊土 砂輸送量の推定精度が大幅に向上していることが分かる. このときの相対差は，隅田川を除き，概ね $30 \%$ 以内に入 っており，一般的な $L-Q$ 式の誤差が $20 \sim 30 \%$ 程度存在する ことを考慮すると ${ }^{17)}$ ，この移動平均值に対する $L Q$ 式の 精度が概ね良好であることが分かる．なお，隅田川の観 測地点は, 感潮域に位置し, かつ, 出水時の流量と比べ

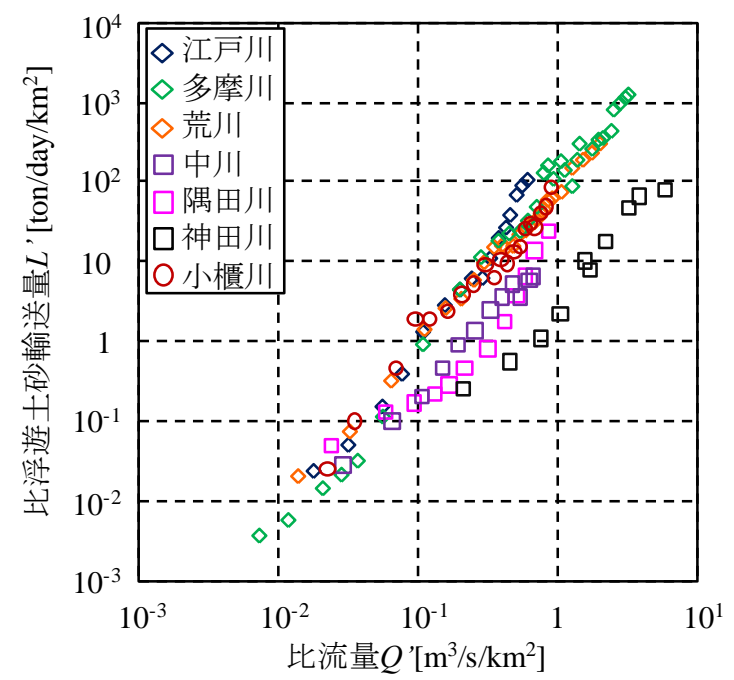

\section{図一4 各河川における $L^{\prime}-Q^{\prime}$ 関係の比較（移動平均値 を採用）}

て潮汐による流量が同程度となることもあることを考慮 すると, 元々 $L-Q$ 関係が一意の関係に成り立ちにくいため, $L-Q$ 式の推定精度が移動平均值を用いた場合でも低下した ものと考えられる.

\section{（3）河川間の $L-Q$ 関係の比較}

表一3に示すように， $L-Q$ 式中の係数 $b$ 概ね 22 となっ おり，一般的なウォッシュロードの結果 ${ }^{19)}$ と近いが，詳 細に見ると河川毎に係数bは異っており, 河川間に $L-Q$ 関 係の差異が生じている.この要因を明らかにするべく河 川間の $L-Q$ 関係を比較するために，浮遊士砂輸送量 $L$ と流 量 $Q$ をそれぞれ流域面積で除した比浮遊土砂輸送量 $L$ ‘比 流量 $Q ’$ 相関図を図一4に示す。ここでは，浮遊土砂輸送 量の推定精度が良好であった移動平均值データを採用し ている. これを見ると, 同一の比流量における比浮遊土 砂輸送量の大きさは，大河川（江戸川，多摩川，荒川） $\doteqdot$ ‘樻川>中川う隅田川>神田川の順序となっている. このうち, 比浮遊土砂輸送量が大きい大河川や小樻川は, 表一1に示すように, 山林の割合が50\%以上と高くなって いる. 一方, 残りの3河川は山林率が低く, 市街地率が高 くなっており, 神田川では市街地率が $98 \%$ に達している.

このようなことから，各河川における流域の土地利用 特性と $L-Q$ 式中の係数 $b$ を比べたものを図一5に示す.ここ では，流域の土地利用割合として山林，市街地，その他 に分類して表示している. また，図中の係数bは移動平均 值に対する結果である。 これより，山林率が高いほど係 数bは大きくなるように見受けられる. そこで，土地利用 特性のうち山林率と市街地率と係数 $b$ との間における重回 帰分析を，以下の式を用いて実施する.

$$
b=x_{1} A_{f}+x_{2} A_{u}+x_{3}
$$




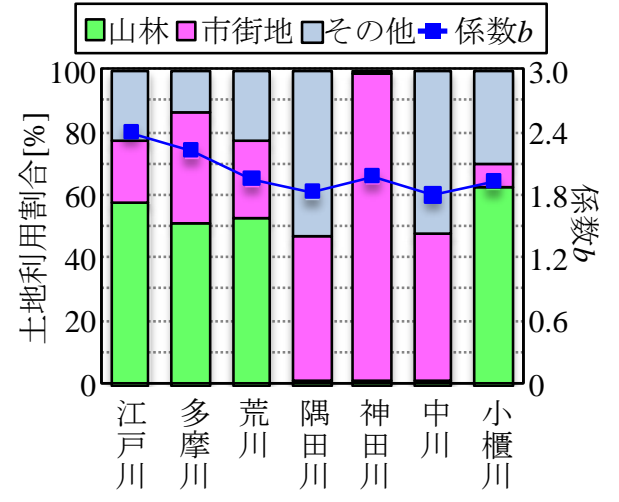

図一5 各河川における移動平均值に対する $し$ 式中の係 数 $b$ と流域土地特性の関係 (土地利用割合を山林 率，市街地率，その他に分類)

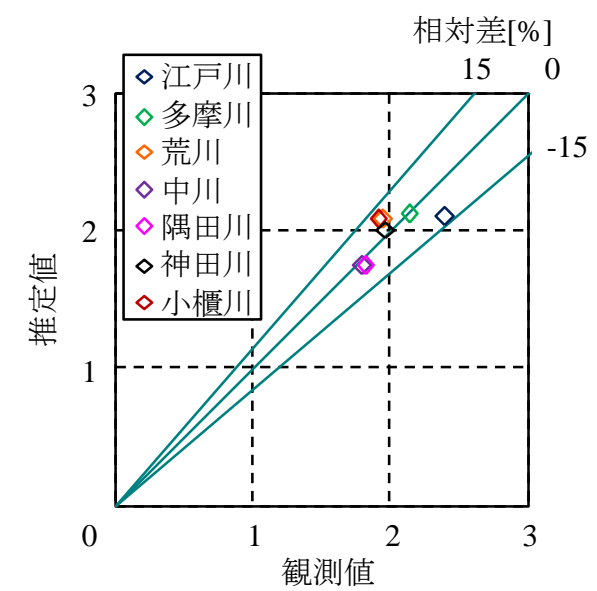

図-6 L-Q式の係数 $b$ に関する観測值と推定値の比較 （観測值には移動平均值に対する結果を採用）

ここで， $A_{f}$ は山林率， $A_{u}$ は市街地率をそれぞれ表す。 重回帰分析の結果，係数 $x_{1} ， x_{2} ， x_{3}$ は各々 $0.0091 ， 0.0053$, 1.4891 という值が得られた。 これより，山林率の係数 $x_{1}$ は 正であり，かつ，市街地率の係数 $x_{2}$ よりも相対的に大き くなっており，山林率が大きいほど土砂生産量が大きい ことを示している.

この係数 $b の$ 推定式の精度を検証するために, 係数bに 関する観測值と式（1）による推定結果を図一6に示寸. これより，7河川共に，係数 $b$ の推定值は概ね観測值と一 致しており，全7河川において相対差が $\pm 15 \%$ 以内という 良好な推定結果となっていることが分かる.このように, 浮遊土砂輸送量に関する $L-Q$ 式中の係数bは，著者らが別 途行ったT-NやT-P，COD と同様に ${ }^{20)}$ ，流域の土地利用特 性と密接に関連し，それらから概祊良好に推定し得るこ とが明らかとなった。

\section{4. 東京湾への浮遊土砂供給量の推定}

前章の結果に基づいて, 各河川における浮遊土砂輸送 量を算定し，流域から東京湾への浮遊土砂供給量を算出 する.ここでは，各河川河口地点における浮遊土砂輸送

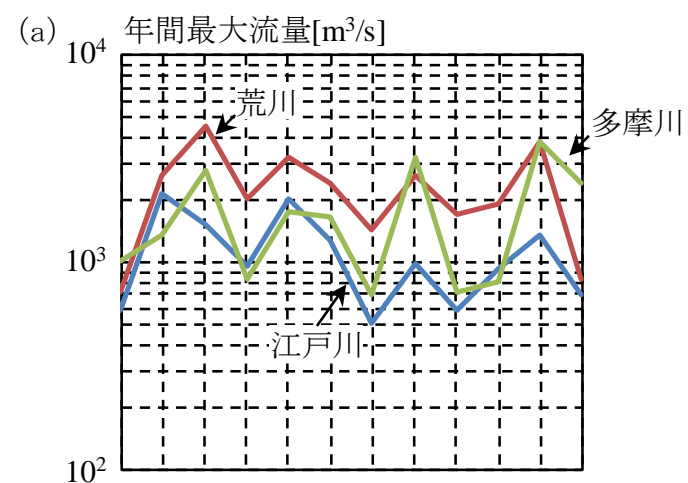

（b）年間浮遊土砂供給量[百万ton]

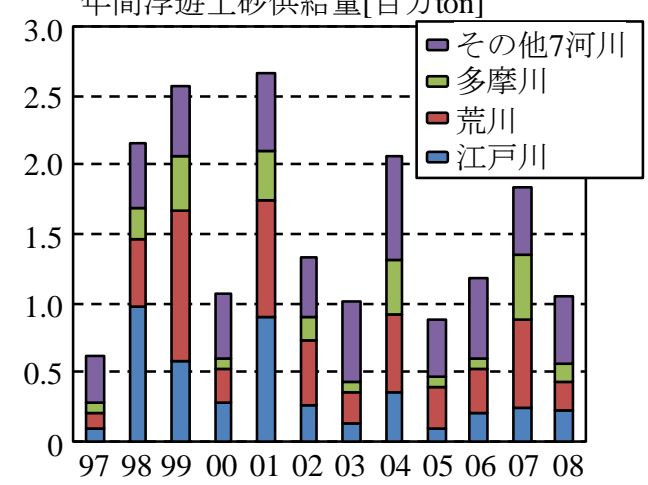

図-7 年間最大流量 (a) と東京湾への年間浮遊土砂供給 量 (b) の経年変化（その他 7 河川は隅田川, 中川, 神田川，小櫃川，養老川，小綡川，鶴見川)

量を算出するために，精度検証がなされている移動平均 值に対する $L-Q$ 式を採用することとし，その係数は表一3 に示す通りである．また，主要10河川のうち観測を行っ ていない養老川，小系川，鶴見川については式（1）と流 域土地利用特性を用いて係数 $b$ を推定している. 同じくL- $Q$ 式中の係数にに関しては, 平常時に行われている公共用水 域データの流量とSS，上記で得られた係数 $b$ を $L-Q$ 式中に 代入し，係数 $a$ を求めている。 これらの3河川における係 数 $a ， b$ の推定結果は表一3に示寸通りである.

このようにして得られた東京湾への年間浮遊土砂供給 量の経年変化を図一7に示寸。ここでは，江戸川，荒川， 多摩川とその他 7 河川に色分けし，1997年から2008年ま での結果を表示している．また，大河川の年間最大流量 の経年変化も図示している。これより，年間浮遊土砂輸 送量は61万ton～267万tonまで大きく変化しており，大き な出水イベントが生じた1998，1999，2001，2004，2007年 に関しては浮遊士砂供給量も大きい．また，この期間の 年間平均值は154万tonとなっている. また，全体に対する 各河川の寄与を見てみると，全般的には，江戸川・荒川・ 多摩川の大河川の結果が大きくなっており，その様子は 大出水が生じた年に顕著になっている．また，それらの 大河川の浮遊士砂輸送量が全体に占める割合は 42 2 80\% であり，この期間での平均值は66\%である. 図一4に示す ように，L冲関係では大きな比浮遊士砂輸送量を示した 
小櫃川は，大河川に比べ相対的に流量が小さいため，年 間浮遊土砂輸送量が小さくなっている.

なお，東京湾への浮遊土砂供給量を算定する上では， 新たな水質指標である透明度の評価を考えると, 粒径別 浮遊土砂供給量を求めることは必須であり，その一部は 既に報告している ${ }^{10)}$. 著者らは, 粒径別浮遊土砂輸送量 の実測值を十分蓄積しつつあるので，今後は，これらの データ解析を鋭意進め, 粒径別の $L-Q$ 関係の把握や東京湾 への粒径別浮遊土砂供給量を算出する予定である.

\section{5. 結論}

本研究では，東京湾流域を対象として構築されたSSモ ニタリングネットワークに基づいて, 浮遊土砂輸送量と 流量の関係 $(L-Q$ 関係 $)$ や東京湾 $の$ 浮遊土砂供給量につ いて検討した. 得られた結論は以下の通りである.

（1）浮遊土砂輸送量評価方法として, 流量と浮遊土砂 輸送量に関する移動平均データを作成し, それに $L Q$ 式を 適用すると, 生データを用いる場合よりも浮遊土砂輸送 量の推定精度が大幅に向上することが示された。

（2）東京湾流入河川間の $L^{\prime}-Q$ 関係を比べたところ, 流 域の山林率が $50 \%$ 以上の江戸川, 荒川, 多摩川や小櫃川 における比浮遊土砂輸送量が大きくなっている.

（3）重回帰分析の結果， $L-Q$ 式の係数 $b$ は流域の山林率 と市街地率から推定することは可能であり, その推定式 による係数 $b の$ 算定精度は土15\%以内に収まる.このこと から, 流域情報から $L-Q$ 式中の係数を良好に推定し得るこ とが示された。

（4）東京湾への浮遊土砂供給量を算出したところ，年 間供給量は 61〜267万 ton と変化し, 1997年～2008 年の平 均值は 154 万 ton となった。 それには，大河川（江戸川, 荒川，多摩川）の影響が大きく，これらの大河川におけ る浮遊士砂供給量の全体に占める割合は 42～80\%, 平均 して 66\%と高いことが明らかとなった。

謝辞 : 国土交通省関東地方整備局江戸川河川事務所・荒 川下流河川事務所，京浜河川事務所，水資源機構・利根 導水総合管理所, 東京都水道局, 千葉県亀山・片倉ダム 管理事務所には流量や水質データをご提供して頂いた. 現地観測の実施や水質分析には，東京理科大学理工学部 土木工学科水理研究室学生諸氏に大変お世話になった. ここに記して謝意を表する.
参考文献

1) 中央環境審議会 : 第6次水質総量規制の在り方について (答 申) , pp.1-15, 2005.

2）安藤晴夫，柏木宣久，二宮勝幸，小倉久子，川井利雄 : 1980 年以降の東京湾の水質污濁状況の变遷について 一公共用 水域水質測定データによる東京湾水質の長期变動解析一, 東京都環境科学研究所年報, pp.141-150, 2005.

3) 中央環境審議会:第 7 次水質総量削減の在り方について(答 申) , pp.1-70. 2010.

4) 二瓶泰雄・大塚慧・影山英将・広瀬久也 : 東京湾における 流入負荷の経年変化, 海岸工学論文集, Vol.55, No.2, pp.1226-1230, 2008.

5）坂井文子，二瓶泰雄，江原圭介，臼田美穂，重田京助，大 塚慧 : 江戸川・荒川・多摩川・中川における出水時栄養塩・ COD負荷特性，水工学論文集，Vol.52，pp.1117-1122，2008.

6) 横山勝英, 藤塚慎太郎, 中沢哲弘，高島創太郎：多点濁度 観測による筑後川水系のSS 流出・輸送特性に関する研究, 水工論文集, Vol.52, pp.553-558，2008.

7) 高田秀重 : 陸域から沿岸海域への物質フラックス, 沿岸海 洋研究, Vol.34, No.2, pp.111-117, 1997.

8) 横山勝英, 藤田光一 : 多摩川感潮域の土砂動態に関する研 究，水工学論文集，Vol.45, pp.937-942，2001.

9）東京湾河口干潟保全検討会 : 東京湾河口干潟保再生検討報 告書, $302 p, 2004$.

10）重田京助，二瓶泰雄，坂井文子，大塚慧 : 東京湾主要流入 河川における浮遊土砂輸送特性に関する基礎的検討，水工 学論文集, Vol.52, pp.913-918, 2008.

11）二瓶泰雄, 重田京助, 伊藤雅人, 星野彰成, 福田昌洋, 加 藤靖之: 東京湾流入河川における土砂輸送·底質環境特性, 土木学会論文集 B2 (海岸工学), Vol.B2-56, No.2, pp.1171-1175, 2009.

12）二瓶泰雄，高村智之，渡邊敬之 : 東京湾主要流入河川にお ける流量モニタリングの現状と課題, 海岸工学論文集, Vol.54, pp.1221-1225, 2007.

13）二瓶泰雄，木水啓 : H-ADCP 観測と河川流計算を融合した 新しい河川流量モニタリングシステムの構築，土木学会論 文集 B，Vol.63，No.4，pp.295-310，2007.

14）武田育郎: 水と水質環境の基礎知識, オーム社, pp.119-166, 2001.

15) Williams, G. P.: Sediment concentration versus water discharge during single hydrologic events in rivers, J. of Hydrology, Vol.111, pp.89-106, 1989.

16）海老瀬潜一: 污濁物質の降雨時流出特性と流出負荷量, 水 質污濁研究, Vol.8, No.8, pp.31-36, 1985.

17) 二瓶泰雄，木水啓，植田雅康，中岡亮，望月健 : 陸域環境 負荷評価のための調査方法及び解析方法に関寸る検討〜江 戸川を例にして〜，海岸工学論文集，Vol.52，№.2， pp.1106-1110, 2005.

18）滝岡健太郎，二瓶泰雄，坂井文子 : 大河川の栄養塩 - COD 負荷に関する出水規模別 $L-Q$ 関係の検討，水工学論文集， Vol.54, pp.1381-1386, 2010.

19）吉川秀夫 : 流砂の水理学, 丸善, pp.141-144，1985.

20）二瓶泰雄，田中辰弥，滝岡健太郎：出水時水質データが無 い河川における $L-Q$ 式推定法の一提案, 土木学会論文集 B2 (海岸工学), Vol.66, pp.1176-1180, 2010. 